Provided for non-commercial research and education use. Not for reproduction, distribution or commercial use.

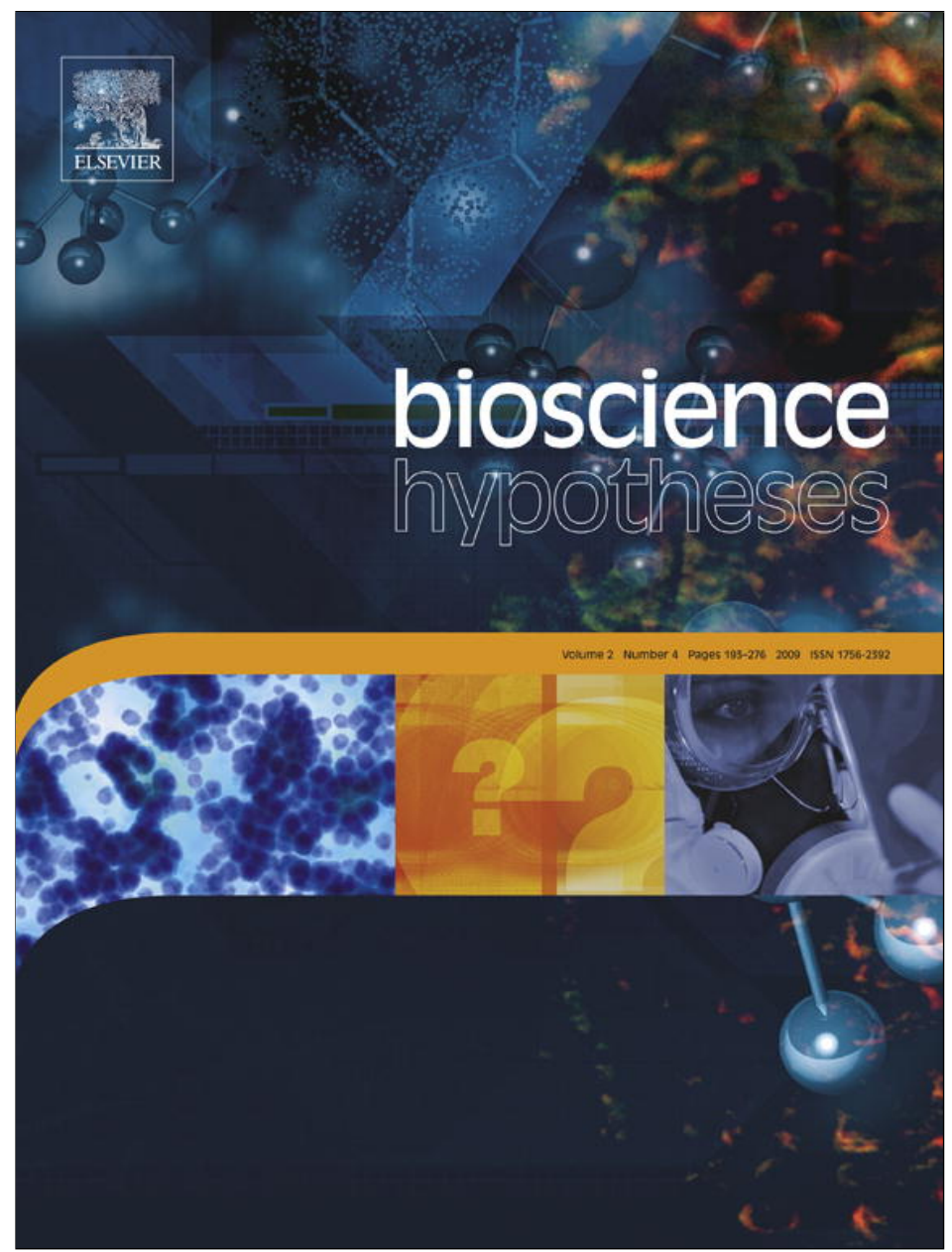

This article appeared in a journal published by Elsevier. The attached copy is furnished to the author for internal non-commercial research and education use, including for instruction at the authors institution and sharing with colleagues.

Other uses, including reproduction and distribution, or selling or licensing copies, or posting to personal, institutional or third party websites are prohibited.

In most cases authors are permitted to post their version of the article (e.g. in Word or Tex form) to their personal website or institutional repository. Authors requiring further information regarding Elsevier's archiving and manuscript policies are encouraged to visit:

http://www.elsevier.com/copyright 


\title{
Not my brother's keeper: A thought experiment for Hamilton's rule
}

\author{
Lonnie W. Aarssen
}

Department of Biology, Queen's University, Barrie Street, Kingston, ON, Canada K7L 3N6

Received 16 December 2008; received in revised form 16 February 2009; accepted 20 February 2009

\section{KEYWORDS}

Fitness;

Hamilton's rule;

Selection;

Selfish genes

\begin{abstract}
The now popular 'selfish gene' view defines evolutionary fitness at the gene level - in terms of the number of gene copies residing in future generations (or propelled from previous generations). Yet, most current biology textbooks still apply the concept of fitness to the individual, where it is defined more traditionally as the number of descendants residing in future generations. The existing literature remains ambiguous regarding whether one of these concepts is more meaningful than the other, or whether they both represent legitimate, functional definitions of fitness. In support of the latter view, I present a composite perspective that recognizes the gene as evolutionarily 'selfish', but also the individual as a 'selfish vehicle' for resident genes. Hamilton's rule explains, based on genetic relatedness, why natural selection has favoured behaviours that compel individuals (as 'donors' of help) to act for the good of copies of their genes residing in close kin ('recipients'). I propose however, that natural selection should particularly favour helping behaviours directed at those recipient kin who have the highest relative probability of being the vehicle for a remarkably adaptive newly mutant gene, weighted by the proportion of genes shared with the donor. According to this 'adaptive-genetic-noveltyrescue' (AGNR) hypothesis, these favoured vehicles for shared gene copies are more likely to involve direct descendants (e.g. offspring) than other close kin from one's collateral lineage (e.g. siblings), even when the donor (e.g. a father) shares fewer genes with an offspring (e.g. a son) than with a sibling (e.g. a brother). (c) 2009 Elsevier Ltd. All rights reserved.
\end{abstract}

\section{Introduction}

"I'm not my brother's keeper, though he be strong or weaker" - The Flaming Ember

In the Old Testament story, Cain killed his brother Abel because God accepted Abel's offering but not Cain's. When

E-mail address: aarssenl@queensu.ca
God inquired concerning Abel, Cain responded, "Am I my brother's keeper?" (Genesis 4:9). Most people are more likely to help brothers than to kill them. In fact, we are especially inclined to care for close kin, like siblings, more than distant relatives or non-relatives. The evolutionist understands this variation in level of helping behaviour as a consequence of variation in the number of shared genes. According to 'Hamilton's rule' [7], the expected magnitude of fitness benefit $b$ enjoyed by a recipient relative, should 
be a function of the degree of genetic relatedness $r$, and the magnitude of fitness cost $c$ incurred by the donor relative; helping or 'giving' behaviour should evolve whenever $r b>c$ [5]. Haldane [6] is famous for proclaiming that, while he would not give his life to save his brother, he would die for two brothers.

According to the now conventional view, therefore, it is because genes are 'selfish' that individuals can be compelled (through the effects of these genes on behaviour) to act not just for the good of these resident genes, but also for the good of copies of these genes residing in close kin, such as siblings. The extension of this 'selfish gene' view, espoused by many evolutionists following Dawkins [3], is that individuals don't really have evolutionary fitness; only their genes do; "... we now recognize that individuals matter only as vehicles of gene survival" ([4], p. 46). Yet, most current textbooks in biology continue to define fitness in terms that apply it to whole individuals, and in many cases, only in terms of individuals. Some define it both ways; the recent Barton et al. [1] 'Evolution' text defines fitness as: "The number of offspring left by an individual after one generation. The fitness of an allele is the average fitness of individuals that carry that allele." Does this mean that evolutionary fitness can be defined legitimately either way - in terms of the copying success of individual genes (or alleles), or in terms of the reproductive success of individual organisms? Is one definition more credible than the other? Or do we need both, as Barton et al. [1] suggest. If so, why?

These questions appear not to have been adequately resolved. In this commentary, I present a perspective for supporting both the gene and individual levels as constituent components for understanding evolutionary fitness. I implicitly support the gene-level view, and explicitly defend a compatible conceptual basis for evolutionary fitness applied also to the whole individual.

\section{The paradox of Cain's dilemma}

To illustrate the central premise, consider another story about a fictitious Cain and Abel:

Two young men, Cain and his brother Abel are walking along a pier. Cain is carrying his infant son. Abel also has an infant son who is with his mother on the shore. A storm on the sea is building quickly and Cain despairs when a large wave washes up and carries his son off the pier. His brother Abel is also swept away, unconscious after striking his head on the way down off the other side of the pier. Both disappear below the surface of the water, and will drown without Cain's assistance. But Cain can save only one. After only the briefest of hesitation, Cain dives in quickly to rescue his son at the expense of his brother.

Anyone who might read this story could relate to the agonizing moral dilemma faced by Cain, and we can predict with equal certainty that virtually every reader would react to Cain's decision with approval. There may be several factors, including cultural variation, and differences in age and health that might affect the extent to which fathers might generally favour the welfare of sons over brothers. Nevertheless, when presented with the above story, upperyear university students (representing several cultures) in my course on 'Evolutionary Ecology of Humans' were asked to "select which one of the following statements best describes your reaction to this story: (a) Cain's decision to save his son is what one would normally expect a person to do under these very difficult circumstances; or (b) Cain's decision to save his son is surprising; one would normally expect a person to save a brother rather than a son under these circumstances." Out of the 302 students who answered the survey, 284 selected (a) and only 18 selected (b).

The Cain of our story causes his brother's death just as surely as the Cain of Genesis; only the details of motive differ. We are more sympathetic to the more modern Cain, however - even supportive, despite that Cain's decision apparently contradicts Hamilton's rule. In this thought experiment - call it 'Cain's dilemma' - the paradox for Hamilton's rule follows because Cain allows his brother's death, despite that he shares more gene copies with his brother than with his son. All three males will share their $Y$ chromosome genes, and Cain and his brother will share, on average, half of their remaining genes, including half of the 1000 or so genes that reside on their X-chromosomes received from their common mother. Cain and his son, however, while also sharing half of their autosomal genes, share not a single X-chromosome gene. Many of the genes on the X-chromosome may not be expressed in human males [10], but they are nevertheless important in terms of potential fitness because unexpressed $\mathrm{X}$-chromosome genes in fathers, brothers and sons, will indeed be expressed to advantage in their future daughters.

Accordingly, if Hamilton's rule is correct - and if only genes have fitness, and "...individuals matter only as vehicles of gene survival" [4] - then as a vehicle for shared genes, Cain's brother, it would seem, should 'matter' at least as much as Cain's son. Roughly half, and possibly more than half of the respondents in my survey, it would seem, should have been surprised by Cain's decision to save his son instead of his brother. Yet, even if Cain and Abel were identical twins, sharing $100 \%$ of their genes, most readers of his story, I submit, would still expect Cain, perhaps after a bit more hesitation, to sacrifice his brother in order to save his son. A typical male in prehistoric environments is likely to have encountered many opportunities for helping and saving the lives of both brothers and sons. The paradox of 'Cain's dilemma' then is that we are inclined so readily to conclude that the Cain in our story on the pier unequivocally did the 'right' thing by sacrificing his brother to save his son - the only thing in fact that anyone could reasonably be expected to do under the circumstances. Why is this so?

Perhaps the simplest interpretation is to invoke the role of cultural evolution; in other words, our contemporary inclination to save offspring before siblings might be just a product of the transmission of popular memes - i.e. because it is currently more 'fashionable' to be so inclined (and perhaps historically this was not always the case). This cannot be discounted, but here I will explore other interpretations that might be found from closer examination of Hamilton's rule. 


\section{Costs and benefits in Hamilton's rule}

If we can expect helping behaviour to evolve whenever $r b>c$, then behaviour that favours a son's welfare (over a brother's) could evolve if the cost (to the copying success of Cain's genes) is generally lower, or if the benefit (to the future copying success of genes shared with Cain) is generally greater, when protecting a son's welfare than when protecting a brother's welfare.

Is there lower cost (to the future copying success of Cain's genes) through elimination of sibling rivalry? Cain might stand to benefit from his brother's death if it meant greater access to resources that may be available within the family group (represented in modern times by estate bequeathal). If available, these 'extra' resources could be used to help support not only Cain's current son, but also the future copying success of all of Cain's genes. If they had gone to support Abel, however (in the event that he had been rescued by (ain) these resources could have supported only the copying success of Abel's genes, about half of which are not shared with Cain. It remains uncertain, however, whether this potential resource advantage from a sibling's death was a broadly general feature in human evolution, or whether it manifested primarily within just the wealthy minority. Males have probably always competed for mates to some extent with their brothers, but no more intensely than with neighbouring unrelated males. It is reasonable to assume that most human families, on a global scale throughout history, were (like today) relatively impoverished; hence, any resource benefit from a sibling's death would be contingent upon whether a significant pool of shared 'family' resources even existed at all - and if so, whether they had already been divided or otherwise dispersed by the time that brothers were adults (as in the pier incident), with independent families of their own.

Is there greater benefit (to the future copying success of genes shared with Cain) through greater certainty of genetic relatedness? Perhaps a father is more likely to save his son because, on average, males have reason to be more certain of their genetic relationship to their alleged offspring than to their alleged siblings. However, the opposite is more likely. Research on sexual jealousy (e.g. [8]) suggests that a man is likely to be more anxious about the sexual fidelity of his lover/partner/spouse than that of his mother. Moreover, Cain is likely to have considerable (if not complete) certainty that he shares at least the same mother with Abel, which contrasts with the unavoidably lower certainty that has applied generally for males regarding their paternity, throughout evolutionary history.

Is there lower cost (to the future copying success of Cain's genes) through lower effort needed to protect a son's future welfare? The opposite is more likely. Cain's adult brother, by his own devises, will generally be just as capable of securing his own safe passage through most of the mortality risks of adult life, with little to be gained by assistance from Cain (notwithstanding the particular incident on the pier). In other words, on the pier, prior to the storm, it would generally be expected to cost Cain virtually nothing in order for the fitness potential of his brother's shared gene copies to be maintained at their current level.
In contrast, it would cost Cain considerable effort (through the many years ahead of raising his son to reproductive maturity) to assist in elevating the fitness potential of his infant son's gene copies to the same level that his brother's gene copies had on the pier. Importantly, this resource investment would be unavailable for supporting Cain's future offspring. Hence, the cost to the future copying success of Cain's genes is likely to be higher by saving his infant son compared with saving his brother.

Is there greater benefit (to the future copying success of genes shared with (ain) through greater future reproductive value in an infant son? It is reasonable to suppose that natural selection might reward greater copying success for shared genes when individual helping investments are directed at those available kin (all else being equal) who have the greatest future reproductive value. But in the present case, this would probably apply to Cain's brother, not his son. Reproductive value of human males does not dramatically decline with age as in females. Throughout the predominantly polygynous evolutionary history of humans, older males have had more time to amass resources and hence opportunity to attract, coerce and support more mates, and to father offspring, even late into their lives. Even more importantly, a brother (who will usually be older than an infant son), is a 'proven survivor', having already lived successfully through the vulnerable infant stage, where mortality risk has been routinely high throughout human evolutionary history. An infant son must pass through many years of mortality risks before he is even capable of reproductive maturity, whereas the brother Abel on the pier is already reproducing (with an infant son of his own) and capable of ongoing reproduction. The son therefore has a far greater chance than the brother of dying without reproducing at all. This means that presently (in the story on the pier) the reproductive value of the brother is probably greater than that of the son.

\section{Resolving the paradox of Cain's dilemma}

As Dawkins [4] illustrates, because of genetic recombination during sex, it is possible - in fact quite likely - that for many of your very distant ancestors, not a single one of their genes now resides in you. Similarly, many, perhaps most of your very distant descendants - if eventually you have some - will probably carry not a single gene copy that can be traced back to you. As a measure of evolutionary fitness, therefore, counting gene copies ultimately matters more than counting descendants. Why then does Cain on the pier care so obviously about copies of his genes residing in his descendant (son) more than the copies of his genes residing in his sibling (brother)? Why are we so quick to approve of Cain's decision to sacrifice his brother in order to save his infant son?-even though: (i) Cain would be saving fewer shared gene copies by saving his son; (ii) Cain would probably be less certain of his genetic relationship to his son; (iii) it would cost Cain considerable future effort to secure survival to reproductive maturity for his son (but no effort for his brother); plus (iv) Cain's infant son can be expected to have lower future reproductive value, i.e. he has a much higher probability (compared with Cain's brother) of dying before reproducing anyway - even in 
spite of Cain's efforts to prevent it. In terms of the cold hard calculation of gene copies being propelled into future generations, it seems that greater success for Cain would be expected if he saved the gene copies residing in his brother rather than those in his infant son. Moreover, Cain's gene copies lost in his son could then be replaced by quickly mating to replace the son with another infant offspring in just a few months hence-and in this event, therefore, Cain's lost parental care investment in the first son would represent only a small fraction of the parental care time that Cain would need to invest anyway in order to raise the second infant to reproductive maturity.

Explanation of our paradox may lie in the possibility that evolution is just not 'clever' enough to take account of all this. Maybe we are 'hard-wired' to be more protective of an infant offspring, simply because on average, a brother will usually be older, and so will normally be expected, most of the time, to be better equipped to take care of himself notwithstanding Abel's particular incapacitation on the pier. In other words, any behavioural module that might promote quick assessment of relative need for kin in an emergency (such as the pier incident), has just not had historical opportunity to be strongly favoured by selection - especially given that saving a son, after all, does successfully minimize the cost of losing current copying success for Cain's genes (i.e. those currently residing in his son on the pier). [Similarly, the concern (mentioned above) for an identical twin versus a non-twin sibling, may not be proportional to the percentage of shared genes simply because the historical frequency of identical twins in human evolution has been so exceedingly rare.]

In the survey responses from my students, however, there was no urgency for a quick decision; time was available for considered reflection on the fact (in the story) that both the brother and the infant son were equally unable to help themselves. Yet respondents still approved of Cain's decision to save his son and sacrifice his brother. One might argue that there is greater risk to Cain's own life by saving his unconscious brother who would be heavier and so more difficult to rescue. Respondents were not asked to convey the reasons for their choices, but it is unlikely that they involved calculations (consciously or unconsciously) of relative body mass in an adult brother versus an infant son. More probably, the reasons involved personal projections of a stronger emotional bond with one's offspring than with one's sibling - even though most of the respondents had siblings of their own, while none had offspring (although they were all old enough to be parents). The critical question then remains: why is emotional bonding routinely stronger for one's direct lineage than for one's collateral lineage?

\section{The 'adaptive-genetic-novelty-rescue' (AGNR) hypothesis}

\section{"Evolution is cleverer than you are" - Leslie Orgel}

Perhaps there is a lesson here from 'Orgel's rule' (above; credited to renowned chemical evolutionist, Leslie Orgel; http://en.wikipedia.org/wiki/_Orgel's_rule). I propose the following hypothesis for the paradox of Cain's dilemma: By saving a son before a brother, there is greater potential benefit - to the future copying success of genes shared with Cain - through greater probability of rescuing adaptive genetic novelty from extinction. Major new adaptive variation requires mutation, and each new adaptive mutant gene originates (possibly) only once, in one particular individual progenitor, and only very rarely. Hence, historically and periodically within all evolutionary lineages, the genes residing in a few certain individuals (or their mates) included remarkably adaptive newly mutant genes found only in those respective individuals, and it was only through the reproductive success of the offspring of these particular individuals that these beneficial newly mutant genes had any chance of being propelled into future generations. Importantly, other resident genes from these ancestral individuals were propelled together with these beneficial newly mutant genes. Accordingly, if a son generally has a greater chance than a brother of being a 'vehicle' for a remarkably adaptive newly mutant gene, it may be of vital importance to the fitness of a father's resident genes, to be 'hard-wired' to favour the welfare of his son ahead of his brother. In fact, we can identify at least a two-fold potential fitness advantage to behaviours that favour the success of offspring over siblings.

Here's why. Cain and Abel share about half of their genes, but some of them will have been randomly mutated in the gametes from their parents that produced Cain, and some (probably a different set) will have been randomly mutated in the gametes from their parents that produced Abel. If Cain were to save the life of his brother Abel, there would be only two 'chances' of potentially saving a remarkably adaptive newly mutant gene - the ones that might have originated within gametes from either of Abel's parents that produced Abel (Fig. 1). In comparison, by saving his son's life instead, Cain invests in at least four chances of potentially rescuing a remarkably adaptive newly mutant gene from extinction (Fig. 1): a mutation that might have originated within gametes from paternal grandparents, one that might have originated within gametes from maternal grandparents, plus one that might have originated within Cain's gamete that produced his son, and also one that might have originated within the maternal gamete that produced Cain's son.

Note that in the above scenario, it is implied that opportunities for mutations are, on balance, a good thing. In other words, if two of your kin share the same number of genes with you, if you must choose, it is better (for your potential fitness) to save the one that is more likely to carry recent adaptive genetic novelty - i.e. the one that has had opportunity to be affected by a greater number of recent independent mutation-generating events. The crucial point is that, on average, this will apply to your offspring ahead of your sibling (Fig. 1). According to Ridley [9] (paraphrasing George Williams), " ... there is no evidence yet found that any creature ever does anything other than try to keep its mutation rate as low as possible. It strives for a mutation rate of zero" (p. 63). But, "evolution depends on the fact that it fails" (p. 63, italics added). In fact, recent research has suggested that under certain conditions higher mutation rates may be favoured by selection [2].

Within most generations of course there are no offspring that bear any remarkably adaptive newly mutant genes. 


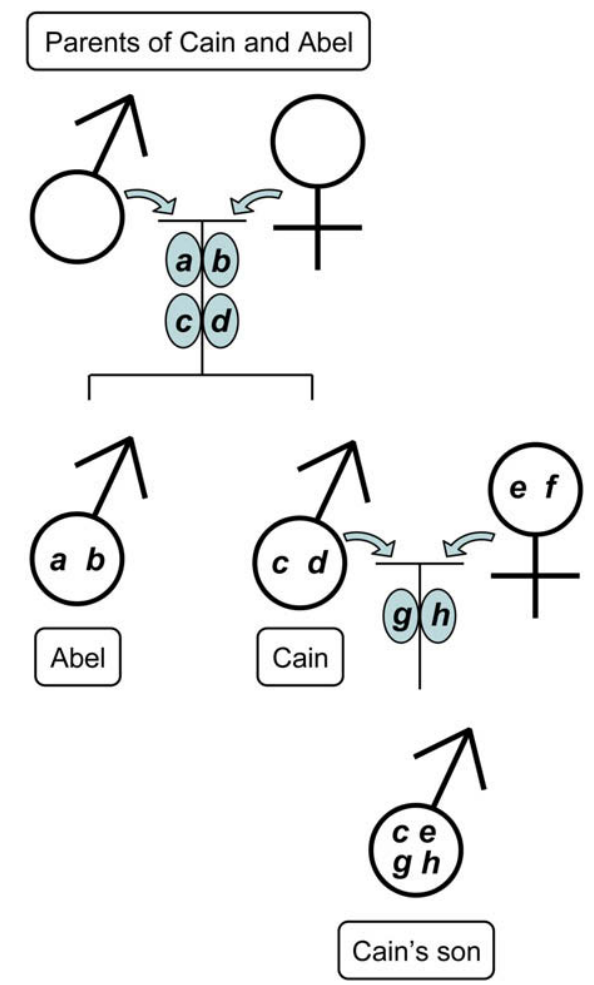

Figure 1 Comparison of the expected relative frequency of adaptive, recently mutated genes in a sibling versus an offspring. Cain and his brother Abel (see story in text) can be expected, on average, to receive the same number of adaptive newly mutant genes $(a, b, c, d)$ that might have their origin within gametes (shaded ellipses) from either of their common parents. Cain's son however, can be expected to receive not only an adaptive newly mutant gene, $c$ (and/or $d$ ) that might originate from his paternal grandparents (and would thus be shared with Cain), but also an adaptive newly mutant gene, $e$ (and/or $f$ ) that might originate from his maternal grandparents, plus an adaptive newly mutant gene $(g)$ that might originate within the paternal gamete from Cain, plus an adaptive newly mutant gene $(h)$ that might originate within the maternal gamete that produced Cain's son. By favouring the welfare of his son over his brother, therefore, Cain has at least twice the chance of rescuing from extinction a remarkably adaptive newly mutant gene-a gene that could assist in propelling into future generations about $50 \%$ of the particular genes residing in Cain, but NOT the approximately $50 \%$ of gene copies shared with Cain that reside in his brother. [The same prediction of course would apply for inheritance (through parents and grandparents) to daughters and granddaughters.]

Over the long term, however, I propose that fitness dividends would have been paid to our predecessors who were 'hard-wired' to have greater concern for offspring than for siblings. Because Cain's son is more likely to be a 'vehicle' for a remarkably adaptive newly mutant gene - protecting him represents a better investment in terms of propelling Cain's particular gene copies into future generations a fitness payoff that cannot be extended to the gene copies shared with Cain that reside in his brother. According to the AGNR hypothesis, therefore, humans have inherited inclinations to provide helping behaviour more generously for offspring than for siblings, simply because every one of us is descended from at least one predecessor who was (or who mated with) the early carrier individual of a remarkably adaptive newly mutant gene - one that was, on average, more likely to reside in an offspring than in a sibling (Fig. 1); and so, this gene was successfully propelled from rarity into future generations (and now resides in us) because that ancestor was readily inclined to provide greater safety and care for a son or daughter than for a brother or sister. Modern habits of estate bequeathal are consistent with this; as beneficiaries, offspring are overwhelmingly favoured over siblings [11].

This premium on 'rescuing' adaptive genetic novelty provides the basis for a meaningful concept of evolutionary fitness applied to the whole individual, e.g. $A$ (and not just to a given gene residing in $A$ ). This is because the direct lineal descendants of $A$ will be-more than any other possible contemporary kin-the most valued vehicle for genes shared with $A$, measured by the relative probability of being the carrier of a remarkably adaptive newly mutant gene, weighted by the proportion of genes shared with $A$ (Table 1).

Although saving his son (instead of his brother) provided Cain (and his shared resident gene copies) with a two-fold greater likelihood of fitness promotion through an adaptive newly mutant gene (Fig. 1), it is important to note that this may not have been true for Cain's parents. The genes that were residing in Cain's parents may very well have had higher fitness had Cain saved his brother Abel's life instead. Had his life been spared, one of Abel's future descendants might have been the original 'vehicle' for a different new mutant gene - one that might have conferred even greater adaptation than the new mutant gene considered above that might reside in Cain's son, and that could therefore not have been propelled through the descendants of Cain's son. Nevertheless, this potential fitness advantage for the parents of Cain and Abel would have had lower probability at the time of the pier incident, because it would depend on an uncertain mutation-generating event that had not yet happened - a mutation therefore that Cain on the pier would have had less (or no) opportunity to save compared with the adaptive, recently mutated gene that might already reside in his son on the pier. Adaptive genetic novelty can be 'rescued' through helping behaviour only if it already exists.

Of course Abel's son (safely on the shore with his mother) would have the same probability as Cain's son of being a 'vehicle' for a remarkably adaptive newly mutant gene (Table 1). Hence, the gene copies residing in both Abel's son and Cain's son are equally important to the fitness of the genes residing in Cain and Abel's parents. But importantly, they are not equally important to the fitness of the genes residing in Cain; even if Cain had opportunity to save the life of Abel's son (Cain's nephew), he would be saving, on average, only half as many copies of genes residing in Cain, compared with the gene copies that can be saved in Cain's own son on the pier (Table 1). Note also that if Cain had opportunity to save the life of a grandchild, he would be saving, on average, the same number of gene copies as in Abel's son. However, Cain's grandchild would have a higher probability of being the vehicle of a remarkably adaptive newly mutant gene (Table 1 ), because the 
Table 1 Comparison of relative kin value as 'vehicles' for gene copies shared with a given individual (Cain), as measured by the product $P \times S$, i.e. the relative probability $(P)$ of being a vehicle for a remarkably adaptive recently mutated gene (see Fig. 1), weighted by the expected proportion $(S)$ of gene copies shared with Cain.

\begin{tabular}{llll}
\hline Individual & $\begin{array}{l}\text { Expected } \\
\text { proportion }(S) \\
\text { of gene } \\
\text { copies shared } \\
\text { with Cain }\end{array}$ & $\begin{array}{l}\text { Relative } \\
\text { probability }(P) \\
\text { of being a vehicle } \\
\text { for a remarkably } \\
\text { adaptive recently } \\
\text { mutated gene }\end{array}$ & $\begin{array}{l}\text { Relative } \\
\text { value as a vehicle } \\
\text { for gene copies } \\
\text { shared with Cain }(P \times S)\end{array}$ \\
\hline $\begin{array}{l}\text { Direct lineage } \\
\text { Cain }\end{array}$ & 1.0 & 2 & 2 \\
Cain's son & 0.5 & 4 & 2 \\
Cain's grandchild & 0.25 & 6 & 1.5 \\
Collateral lineage & & & 1 \\
Cain's brother Abel & 0.5 & 2 & 1 \\
Cain's nephew (Abel's son) & 0.25 & 4 & 0.75 \\
Cain's grand-nephew (Abel's grandchild) & 0.125 & 6 & \\
\hline
\end{tabular}

grandchild will have had opportunity to be affected by a greater number of recent independent mutation-generating events (which could be illustrated by adding another generation onto Fig. 1).

We can predict, therefore, that, on average throughout evolutionary history, gene copies residing in one's offspring were propelled into future generations in greater total numbers compared with one's gene copies residing in a sibling. The same prediction applies regarding transmission of the current gene copies residing in Cain on the pier, and of course also the current gene copies residing in his brother Abel. Lucky for Abel, then, that his son was safe on the shore during the storm on the pier, and that in addition, copies of 25\% of Abel's genes (expected on average) were also rescued with his nephew - Cain's son.

\section{Conclusions}

Based on traditional theory derived from Haldane, Hamilton, and Dawkins, evolutionists now routinely assume that we are descended from predecessors who, when possible, were inclined to help copies of their genes residing in kin. But more specifically, I suggest, we are descended from predecessors who were particularly inclined, all else being equal, to help kin whose gene copies were residing together with remarkably adaptive, newly mutant genes. On average, this will have applied more often - with at least twice the probability - to offspring than to siblings. This can explain why we so readily approve of Cain's quick decision (in our story on the pier) to sacrifice his brother to save his son, even though Cain shares more gene copies with his brother. Of course Cain on the pier is not aware of any of this when he decides to save his son, but he is aware of the emotional bond that is stronger for his son than for his brother (as was probably also anticipated by the respondents in my class survey); this is all that is needed to promote greater potential fitness benefit for Cain, and his resident genes, that is afforded by saving his son instead of his brother. There is no reason why the same prediction should not apply also to other species that display parental care behaviours.
It is doubtful, I suggest, that Haldane [6] would have died for two brothers - or three or even four - if, in their place, it meant having to sacrifice a single son or daughter, or perhaps even a single grandchild. Individuals matter not simply "as vehicles of gene survival" [4], and this is because some particular 'vehicles' matter profoundly more than others. The above considerations suggest that direct descendants - offspring in particular - routinely matter, as carriers of gene copies, more than other close kin - siblings in particular. The AGNR hypothesis predicts that even a grandchild should have greater fitness value than a brother as a vehicle of gene copies shared with Cain (Table 1). On this basis, we have a meaningful conceptualization for both genes and individuals as composite components in the definition of evolutionary fitness; i.e. 'self-interest' can be attributed to the level of the gene, and at the same time, to the level of the whole individual, representing a particular collection of resident genes.

Fitness then is the result of both 'selfish genes', and 'selfish vehicles' of genes. Genes cannot propel themselves into future generations. Only whole individuals can propel them as resident genes within individual descendants genes that are propelled only because they work and interact together in the expression of phenotypic traits that reward the reproductive success of the individual. Cain could have saved the shared gene copies residing in Abel from perishing, but he could never have propelled them into future generations. Neither can he propel the shared gene copies residing in his son into future generations. But his son represents the first order transmission of Cain's genes into future generations, including importantly the possible transmission of a highly adaptive newly mutant gene that could carry with it other resident gene copies from Cain into future generations - a newly adaptive mutant gene that can be expected, on average, to have a higher probability of residing in a son than in a brother.

\section{Acknowledgments}

The manuscript benefited from helpful discussions with Adam Chippindale, Troy Day, Michael Higginson, Robert 
Laird, Stephen Lougheed, Bob Montgomerie, Aaron Myron, and Tom Tregenza-although not all of these colleagues necessarily agreed with all of the views presented here. Financial support was provided by a research grant from the Natural Sciences and Engineering Research Council of Canada.

\section{Conflict of interest}

In submitting my paper to Bioscience Hypotheses, I declare no financial or commercial conflicts of interest.

\section{References}

[1] Barton NH, Briggs DEG, Eisen JA, Goldstein DB, Patel NH. Evolution. Woodbury, NY: Cold Spring Harbor Laboratory Press; 2007.

[2] Baer CF. Does mutation rate depend on itself? PLoS Biol 2008; 6(2):e52.
[3] Dawkins R. The selfish gene. Oxford: Oxford University Press; 1989.

[4] Dawkins R. The ancestor's tale. New York: Houghton Mifflin Co.; 2004.

[5] Grafen A. Modeling in behavioural ecology. In: Krebs JR, Davies NB, editors. Behavioural ecology: an evolutionary approach. Oxford: Blackwell; 1991. p. 5-31.

[6] Haldane JBS. Population genetics. New Biology 1955;18:34-51.

[7] Hamilton WD. The genetical evolution of social behaviour. Journal of Theoretical Biology 1964;7:1-52.

[8] Schutzwohl A. Sex differences in jealousy: information search and cognitive preoccupation. Personality and Individual Differences 2006;40:285-92.

[9] Ridley $M$. The red queen - sex and the evolution of human nature. Putnam, New York: Penguin; 1993.

[10] Ross MT, Grafham DV, Coffey AJ, Scherer S, McLay K, Muzny D, et al. The DNA sequence of the human $X$ chromosome. Nature 2005;434:279-80.

[11] Smith MS, Kish BJ, Crawford CB. Inheritance of wealth as human kin investment. Ethology and Sociobiology 1987; $8: 175$. 